\title{
Epidemiology and treatment of osteoporosis in women: an Indian perspective
}

\author{
This article was published in the following Dove Press journal: \\ International Journal of Women's Health \\ 19 October 2015 \\ Number of times this article has been viewed
}

\author{
Anuradha V Khadilkar \\ Rubina M Mandlik \\ Growth and Endocrine Unit, Hirabai \\ Cowasji Jehangir Medical Research \\ Institute, Jehangir Hospital, Pune, \\ Maharashtra, India
}

\begin{abstract}
The number of women with osteoporosis, ie, with reduced bone mass and the disruption of bone architecture, is increasing in India. While data on prevalence of osteoporosis among women in India come from studies conducted in small groups spread across the country, estimates suggest that of the 230 million Indians expected to be over the age of 50 years in $2015,20 \%$, ie, $\sim 46$ million, are women with osteoporosis. Thus, osteoporosis is a major public health problem in Indian women. Low calcium intakes with extensive prevalence of vitamin D deficiency, increasing longevity, sex inequality, early menopause, genetic predisposition, lack of diagnostic facilities, and poor knowledge of bone health have contributed toward the high prevalence of osteoporosis. Bone health may be optimized by creating an environment to achieve peak bone mass during adolescence, maintenance of healthy bone throughout the life cycle, and prevention of bone loss postmenopausal. In Indian women, calcium, vitamin D, and bisphosphonates are the commonest first-line therapies used. The use of other drugs such as hormone replacement therapy, estrogen agonists, calcitonin, parathyroid hormone, and denosumab is decided as per the affordability and availability of treatment options. Major gaps still remain in the diagnosis and management of osteoporosis, thus highlighting the need for more structured research in this area. This review focuses on the epidemiology of osteoporosis in Indian women and available treatments.
\end{abstract}

Keywords: osteoporosis, Indian perspective, epidemiology, treatment

\section{Introduction}

Osteoporosis is characterized by reduced bone mass and the disruption of bone architecture that results in increased risks of fragility fractures, which are the main consequences of the disease. ${ }^{1}$ Osteoporosis-related fractures are associated with substantial pain, suffering, disability, and possibly even death for the affected patients. Further, increasing longevity has resulted in an increasing number of senior citizens globally; life expectancy at present is $\sim 67$ years in India and is expected to increase to 71 years by 2025 and to 77 years by $2050 .{ }^{2}$ Further, $\sim 10 \%$ of the Indian population is older than 50 years at present; however, these figures are likely to go up to $34 \%$ by $2050 .{ }^{1}$ Thus, increasing longevity and a greater proportion of the Indian population over the age of 50 years are likely to result in an increased number of people affected by osteoporosis. In 2013, estimates suggested that $\sim 50$ million people in India had $T$-scores of $<-1 .^{3}$

Habitual low intakes of calcium have been reported in toddlers, adolescents, pregnant and lactating mothers, and postmenopausal Indian women. ${ }^{4-9}$ Given the need to build up peak bone mass during pubertal years and the increased calcium requirements during pregnancy time, lactation, and peri- and postmenopausal years, the situation is critical for Indian women. ${ }^{10,11}$ Milk and milk products are expensive commodities, and the amounts purchased by the lower socioeconomic classes are likely to be meager. ${ }^{12,13}$
Correspondence: Anuradha $\vee$ Khadilkar Growth and Endocrine Unit, Hirabai Cowasji Jehangir Medical Research Institute, Jehangir Hospital, 32 Sassoon Road, Pune 4II 00 I, Maharashtra, India $\mathrm{Tel}+9|2026| 4 \mid 340$ Fax $+9|2026| 4 \mid 340$ Email anuradhavkhadilkar@gmail.com 
Further, the unequal distribution of milk and milk products, with boys and men being served larger portions, is another factor that worsens the situation. ${ }^{14}$ The differences in calcium intakes between sexes are starker in the lower socioeconomic classes. Indian diets are predominantly vegetarian, and the contribution of dairy products to the overall calcium intake is minimal in the lower socioeconomic classes. ${ }^{15}$ Phytates and oxalates in the fiber-rich Indian diet also retard the absorption of calcium. ${ }^{16}$ Government supplementation programs provide pregnant and lactating mothers with $500 \mathrm{mg} / \mathrm{d}$ of calcium through a serving of $165 \mathrm{~g}$ of micronutrient fortified food per day; however, there are no national programs for supplementation for or promotion of bone health. ${ }^{17}$

Although India is a sun-rich country, deficiency of vitamin $\mathrm{D}$ has been reported at all age groups. Avoidance of sunlight exposure due to sociocultural reasons, poor intakes of dietary calcium, environmental pollution, and higher 25(OH)-D-24-hydroxylase enzyme in Asian Indians are some of the reasons for hypovitaminosis D. ${ }^{18}$ Oily fish and other vitamin D-containing foods form a very small part of the Indian diet. Together with the absence of fortification of food products with vitamin D (except oils that have $5-15 \mu \mathrm{g} / 100 \mathrm{~g}$ of oil), only $\sim 1 \%$ of vitamin $\mathrm{D}$ is derived from dietary sources. ${ }^{11}$

The gold standard for the diagnosis of osteoporosis is by dual energy X-ray absorptiometry (DXA). Data suggest that there are $\sim 0.26$ DXA machines per million of the Indian population. Very few of these machines are found in government hospitals; thus, there is limited access to DXA scanners. ${ }^{19}$ Further, studies also suggest that ethnic-specific reference data need to be used for the diagnosis of osteoporosis. A multicentric study using Hologic machines conducted by the Indian Council of Medical Research for generating reference curves for bone density has shown that Indians have lower bone mineral density (BMD) than their North American counterparts. This finding has been confirmed by a report from South India, where authors have reanalyzed the data scored using the National Health and Nutrition Examination Survey data vs Indian data. Authors found that osteoporosis at spine and hip was present in $42.7 \%$ and $11.4 \%$ subjects, respectively, on using the Hologic database and $27.7 \%$ and $8.3 \%$, respectively, on using the Indian reference data. ${ }^{20}$ However, the Indian reference data does not have the incidence of fractures. Further, the data have not been incorporated into DXA scanners and hence cannot be directly applied to lunar scanners. This has led to a confusion among the clinicians with regard to the diagnosis and, hence, the treatment of osteoporosis. Thus, it has been suggested that as the Indian Council of Medical Research database has been shown to underestimate bone density in subjects with hip fracture and to classify subjects with osteoporosis as having osteopenia, the Hologic database was used as a reference for bone density together with a fracture risk assessment tool. ${ }^{20}$

Further, studies also suggest that knowledge about bone health among Indian women is poor. In a study designed to assess knowledge of osteoporosis in educated women, authors concluded that there was a general lack of knowledge about osteoporosis and that there was a need for increased involvement of medical professionals in education about bone health. $^{21}$

Thus, low calcium intakes with extensive prevalence of vitamin D deficiency, poor knowledge about osteoporosis, and difficulties in the diagnosis of osteoporosis in Indian conditions are some of the reasons that have resulted in osteoporosis becoming a major public health problem in India, especially among the Indian women.

Therefore, this narrative, nonsystematic review aims to focus on the epidemiology of osteoporosis in Indian women and available treatments. The major databases searched included MEDLINE, PubMed, Embase, and Cochrane focusing on randomized control trials, reviews, recommendations, and guidelines, especially in the Indian context. Studies selected included those that reported prevalence of osteoporosis, current osteoporosis treatment, and fracture risk with special reference to Indian women.

\section{Epidemiology of osteoporosis Prevalence of osteoporosis}

As discussed earlier, with the increase in life expectancy of Indians, an alarming rise has been noted in the number of women being diagnosed with clinical osteoporosis. While data on prevalence of osteoporosis among women in India come from studies conducted in small groups spread across the country, estimates suggest that of the 230 million Indians expected to be over the age of 50 years in $2015,20 \%$ are osteoporotic women. ${ }^{22}$ Prevalence of osteoporosis ranging from $8 \%$ to $62 \%$ in Indian women of different age groups has been reported by several studies (Table 1).

Fractures following "minimal trauma", ${ }^{23}$ especially of the vertebra, are the most common and earliest manifestations of osteoporosis. ${ }^{24}$ Fractures are also an important cause of morbidity and mortality in Indian osteoporotic patients and have been reported to occur much earlier in Indians compared to people in the West. $^{25}$ However, data on prevalence of osteoporotic fractures, much like the data on prevalence of osteoporosis, are a product of studies carried out in various small groups of people across the country. The Delhi Vertebral Osteoporosis Study (DeVOS) reported a prevalence 
Table I Studies describing the prevalence of osteoporosis among Indian women

\begin{tabular}{|c|c|c|c|c|c|}
\hline $\begin{array}{l}\text { Sr } \\
\text { no }\end{array}$ & $\begin{array}{l}\text { Title of the study } \\
\text { (year) }\end{array}$ & $\begin{array}{l}\text { Study } \\
\text { location }\end{array}$ & Subject details & Method of diagnosis & Prevalence of osteoporosis \\
\hline 1 & $\begin{array}{l}\text { Evaluation of BMD of } \\
\text { women }>40 \text { years of } \\
\text { age }^{84}(2005)\end{array}$ & Mumbai & $\begin{array}{l}200 \text { women attending } \\
\text { well women clinic, } \\
>40 \text { years }\end{array}$ & $\begin{array}{l}\text { BMD proximal femur } \\
\text { and spine-DXA }\end{array}$ & $34 \%$ osteopenia and $8 \%$ osteoporosis \\
\hline 2 & $\begin{array}{l}\text { Bone status of Indian } \\
\text { women from a low-income } \\
\text { group and its relationship } \\
\text { to the nutritional status }{ }^{85} \\
(2005)\end{array}$ & Hyderabad & $\begin{array}{l}289 \text { slum-dwelling } \\
\text { women, } 30-60 \text { years }\end{array}$ & $\begin{array}{l}\text { Hologic DXA at AP } \\
\text { lumbar spine, hip, and } \\
\text { total body }\end{array}$ & $52 \%$ osteopenia and $29 \%$ osteoporosis \\
\hline 3 & $\begin{array}{l}\text { Preliminary screening } \\
\text { of osteoporosis and } \\
\text { osteopenia in urban } \\
\text { women from Jammu using } \\
\text { calcaneal QUS } \\
\text { o6 }(2006)\end{array}$ & Jammu & $\begin{array}{l}158 \text { women, } \\
25-65 \text { years }\end{array}$ & Calcaneal QUS & $\begin{array}{l}36.79 \% \text { osteopenia and } \\
20.25 \% \text { osteoporosis }\end{array}$ \\
\hline 4 & $\begin{array}{l}\text { Prevalence of osteoporosis } \\
\text { among elderly women } \\
\text { living in Delhi and rural } \\
\text { Haryana }^{87}(2007)\end{array}$ & $\begin{array}{l}\text { Delhi and rural } \\
\text { Haryana }\end{array}$ & $\begin{array}{l}430 \text { women, } \\
60-80 \text { years } \\
\text { (I } 25 \text { rural Haryana, } \\
250 \text { affluent urban } \\
\text { area Delhi, and } \\
55 \text { LSC Delhi) }\end{array}$ & $\begin{array}{l}\text { Hologic DXA at hip } \\
\text { and lumbar spine }\end{array}$ & $\begin{array}{l}29 \% \text { osteopenia and } \\
62 \% \text { osteoporosis }\end{array}$ \\
\hline 5 & $\begin{array}{l}\text { Osteoporosis and } \\
\text { osteopenia in India: a few } \\
\text { more observations }{ }^{32}(2009)\end{array}$ & Kerala & $\begin{array}{l}609 \text { persons } \\
(52 \pm 12.8 \text { years }) \\
538 \text { women }\end{array}$ & QUS distal radius & $\begin{array}{l}221 \text { or } 41.1 \% \text { osteopenic women; } \\
237 \text { or } 44.1 \% \text { osteoporotic women }\end{array}$ \\
\hline 6 & $\begin{array}{l}\text { Bone mineral density in } \\
\text { women above } 40 \text { years }^{31} \\
(2010)\end{array}$ & Pune & $\begin{array}{l}\text { I05 women } \\
(50.46 \pm 7.60 \text { years, age } \\
\text { range } 40-72 \text { years })\end{array}$ & $\begin{array}{l}\text { DXA lunar vertebral } \\
\text { measurements lumbar } \\
\text { spine }\end{array}$ & $\begin{array}{l}31.4 \% \text { osteopenia and } \\
14.3 \% \text { osteoporosis }\end{array}$ \\
\hline 7 & $\begin{array}{l}\text { Low bone mass in urban } \\
\text { Indian women above } \\
40 \text { years of age: prevalence } \\
\text { and risk factors }{ }^{8}(2010)\end{array}$ & Pune & $\begin{array}{l}\text { I72 ( } 80 \text { pre- and } \\
92 \text { postmenopausal) } \\
\text { healthy women } \\
\text { ( } 40-75 \text { years) } \\
\text { attending a routine } \\
\text { health check at } \\
\text { Jehangir hospital in } \\
\text { Pune city }\end{array}$ & $\begin{array}{l}\text { Lunar DPX-PRO DXA } \\
\text { BMD lumbar spine } \\
\text { (L2-L4) and dual } \\
\text { femurs }\end{array}$ & $\begin{array}{l}\text { Lumbar spine (L2-L4): } \\
\text { Osteopenia: } 48.4 \% \text { postmenopausal } \\
\text { and } 44.3 \% \text { premenopausal women } \\
\text { Osteoporosis: } 25.8 \% \text { postmenopausal } \\
\text { and } 7.6 \% \text { premenopausal women } \\
\text { Femoral neck: } \\
\text { Osteopenia: } 62 \% \text { postmenopausal and } \\
45.6 \% \text { premenopausal women } \\
\text { Osteoporosis: } 8.7 \% \text { postmenopausal } \\
\text { Total hip: } \\
\text { Osteopenia: } 45.3 \% \text { postmenopausal and } \\
26.7 \% \text { premenopausal women } \\
\text { Osteoporosis: } 2.3 \% \text { postmenopausal } \\
\text { women }\end{array}$ \\
\hline 8 & $\begin{array}{l}\text { Prevalence and related risk } \\
\text { factors of osteoporosis in } \\
\text { peri- and postmenopausal } \\
\text { Indian women }{ }^{47}(2011)\end{array}$ & Chandigarh & $\begin{array}{l}200 \text { peri- and } \\
\text { postmenopausal } \\
\text { women aged older } \\
\text { than } 45 \text { years }\end{array}$ & $\begin{array}{l}\text { Lunar DPX-PRO DXA } \\
\text { BMD at lumbar spine }\end{array}$ & $\begin{array}{l}53 \% \text { had low BMD } \\
\text { (osteopenia or osteoporosis) }\end{array}$ \\
\hline 9 & $\begin{array}{l}\text { Bone health in healthy } \\
\text { Indian population aged } \\
50 \text { years and above }{ }^{33}(201 \mathrm{I})\end{array}$ & Delhi & $\begin{array}{l}\text { I,600 healthy subjects } \\
>50 \text { years of age } \\
\text { ( } 792 \text { males and } \\
808 \text { females) mean age } \\
\text { of } 57.67 \pm 9.46 \text { years }\end{array}$ & DXA & $\begin{array}{l}44.9 \% \text { osteopenia and } 42.5 \% \\
\text { osteoporosis in women }\end{array}$ \\
\hline 10 & $\begin{array}{l}\text { Bone status of women } \\
\text { over } 40 \text { years of age from } \\
\text { two socioeconomic strata } \\
(2012)\end{array}$ & Pune & $\begin{array}{l}58 \text { and } 54 \text { (I I } 2) \\
\text { women (mean age } \\
49.5 \pm 7.2 \text { years) } \\
\text { from USC and LSC, } \\
\text { respectively }\end{array}$ & $\begin{array}{l}\text { Lunar DPX-PRO DXA } \\
\text { BMD at lumbar spine } \\
\text { and total femur }\end{array}$ & $\begin{array}{l}\text { Osteoporosis in the USC women: } \\
\text { I } 2 \% \text { lumbar spine and } 0 \% \text { at femur } \\
\text { Osteoporosis in the LSC women: } \\
33 \% \text { at lumbar spine and I I\% at femur }\end{array}$ \\
\hline 11 & $\begin{array}{l}\text { Cross sectional study of } \\
\text { osteoporosis among } \\
\text { women }^{50}(2013)\end{array}$ & & $\begin{array}{l}\text { I } 58 \text { women, older } \\
\text { than } 35 \text { years of age } \\
(42.5 \pm 3.4 \text { years; wives } \\
\text { of staff })\end{array}$ & $\begin{array}{l}\text { Calcaneal quantitative } \\
\text { ultrasonography }\end{array}$ & $\begin{array}{l}48.1 \% \pm 7.79 \% \text { osteopenia } \\
13.3 \% \pm 5.29 \% \text { osteoporosis }\end{array}$ \\
\hline
\end{tabular}

Abbreviations: BMD, bone mineral density; DXA, dual energy X-ray absorptiometry; AP, anteroposterior; QUS, quantitative ultrasonography; LSC, lower socioeconomic class; USC, upper socioeconomic class. 
of $17.1 \%$ of vertebral fractures among the 415 females subjects (age $>50$ years) enrolled in the study. ${ }^{24}$ Hip fracture rates were reported to be $159 / 100,000$ women over the age of 50 years in Rohtak district, North India. ${ }^{26}$ An incidence of 34.3/100,000 has been reported for low trauma fractures at hip, spine, and wrist. ${ }^{19}$

\section{Risk factors and causes for osteoporosis in Indian women}

Various factors are involved in the etiology of osteoporosis among Indian women. The nonmodifiable factors include sex, advancing age, ethnicity, and genetic factors. Women have a smaller body frame size, are more likely to have lower portions of calcium-rich foods and for socio-cultural reasons are likely to have poor sunlight exposure. Further, estrogen being important for the formation and growth of bone in women, decreased periods of exposure to estrogen during a woman's lifetime may contribute in a major way to the development of osteoporosis. ${ }^{27}$ Though the average age at menarche in Indian girls is $\sim 12.5$ years, age at menopause is often earlier than that seen in Caucasian women. ${ }^{28,29}$ This has been reported to be a significant risk factor for the development of osteoporosis in Indian women. ${ }^{30,31}$ Numerous studies have reported increasing prevalence of osteoporosis with advancing age, and this trend had been observed to a great extent among Indian women than men. ${ }^{31-33}$

Genetic factors, race, and ethnicity also have a very strong influence on peak bone mass. Asian Indian women have been shown to have lower BMD than their Caucasian and Black counterparts. ${ }^{34,35}$ Polymorphisms in the gene for vitamin D receptor in different races have been suggested as a factor responsible for the ethnic differences in BMD. ${ }^{22}$ Associations between vitamin $\mathrm{D}$ receptor gene polymorphisms and estrogen receptor alpha gene polymorphisms with BMD in postmenopausal women have been demonstrated in several studies. $^{36-39}$

The modifiable risk factors of osteoporosis include:

1. Nutritional factors: calcium and vitamin D, the two main nutrients involved in bone health, play a major role in influencing the risk of osteoporosis.

a. Calcium: calcium in the form of hydroxyapatite crystals is deposited in the bone matrix and is responsible for the hardness of bone. Calcium is obtained from the diet through dairy as well as nondairy sources. The bioavailability of calcium from dairy sources is much higher than nondairy sources. Several studies have reported that Indian diets do not meet the recommended dietary allowances of $600 \mathrm{mg} / \mathrm{d}$ of calcium for adult women, which has been recommended by the Indian Council of Medical Research. ${ }^{11}$ One of the reasons for this is the poor consumption of dairy products. According to the reports by Harinarayan et al Indian diets have a higher ratio of phytates to calcium, especially among rural Indians. ${ }^{40}$ Phytates may hinder calcium absorption from the already calcium-deficient diets. Thus, bone remodeling may be retarded, resulting in lower BMD, increasing the risk of osteoporosis.

b. Vitamin D: vitamin D is synthesized in the human skin upon exposure to sunlight. Although India has abundant sunlight, several reports state that Indians suffer from vitamin D deficiency. ${ }^{5,18,40-44}$ Some of the reasons for vitamin D deficiency among Indians may be low sun exposure, traditional clothing (saris, salwar kameezes), inadequate dietary intake, poor vitamin D fortification of food, and highly pigmented skin. ${ }^{19}$ Vitamin D deficiency results in ineffective calcium absorption from the gut, which in turn affects the mineralization of bones. Vupputuri et al in 2006 reported that in urban Asian Indians, "functionally significant deficiency of vitamin D affecting BMD at hip" was quite prevalent. $^{45}$

The findings of the DeVOS suggest that the odds of having osteoporotic fractures in subjects consuming calcium and vitamin D supplements were lower. ${ }^{24}$

2. Nutritional status: poor nutritional status is also an important risk factor for osteoporosis. Body weight $<60 \mathrm{~kg}$ and height $<155 \mathrm{~cm}$ may significantly increase the risk of osteoporosis in women. ${ }^{30}$ A number of pathways link bone and fat, which ultimately serve to develop a skeleton with appropriate BMD, to support the mass it has to carry. Body weight, especially adipose tissue, is the main determining factor for BMD. ${ }^{46}$ A number of studies have demonstrated a positive correlation between body mass index and BMD. ${ }^{47,48}$

3. Lifestyle: urbanization has resulted in a sedentary lifestyle, decreased sun exposure, and lesser physical activity, which are detrimental to bone health. ${ }^{19}$ Physical exercise, especially weight-bearing exercise, helps to improve and maintain muscle and bone strength and also helps to improve body balance. ${ }^{49}$ Lack of exercise has been found to be significantly associated with lower BMD in Indian women. ${ }^{47,50}$

Cigarette smoking, while being a major risk factor for osteoporosis, has been found to be too low among Indian women to majorly increase their risk of osteoporosis. ${ }^{30}$ In 
the DeVOS, it was reported that neither cigarette smoking nor alcohol consumption was significantly associated with prevalent fractures in the study subjects. ${ }^{24}$

4. Medication use: Jha et al have reported a protective effect of hormone replacement therapy (HRT) on bone density of the women subjects in their study; however, their study was not powered to detect the details related to risk factors, and the sample size was small to generalize the results to the masses. ${ }^{51}$ Long-term glucocorticoid use by elderly population has also been reported as a major contributor to the increasing prevalence of osteoporosis in elderly Indian population. ${ }^{19}$

5. Previous history of fractures: while there are studies that have reported history of fractures in the preceding 5 years as a major risk factor, ${ }^{30}$ Marwaha et al report that they did not find the history of previous fractures to significantly increase the risk of vertebral fractures. ${ }^{24}$

\section{Prevention of osteoporosis}

Osteoporosis is a silent disease. However, once fractures occur, they result in pain and disabilities; fractures are also an enormous economic burden. Hence, prevention is critical in this disorder. In postmenopausal women, testing for BMD is based on the risk profile, while for women older than 65 years, measurement of BMD is recommended. Yearly measurement of height is also advised (for vertebral fractures). Suggested lifestyle changes include a diet rich in calcium (up to 1,000-1,200 mg/d) and exposure to sunlight to make or vitamin D supplementation to achieve 800-1,000 IU/d. Regular weight-bearing and muscle-strengthening exercises are also advocated. Further, avoiding behaviors such as smoking that impair bone health and prevention of falls to avoid fragility fractures are important. ${ }^{52}$

\section{Treatment of osteoporosis Calcium and vitamin D}

Calcium with or without vitamin D is the first-line therapy for the prevention of bone loss and osteoporotic fractures; even so, the efficacy of its use in fracture prevention is still uncertain. Reports suggest that the reduction of fractures is significantly greater in supplementation trials, where compliances are high and when at least 1,200 mg of calcium and 800 IU of vitamin D are supplemented. Patients with lower vitamin $\mathrm{D}$ concentrations and poor calcium intakes tend to benefit more than the patients with adequate calcium and vitamin D. ${ }^{53}$ In the Women's Health Initiative (WHI) study, $\sim 36,000$ postmenopausal women (between 50 years and 79 years) received $500 \mathrm{mg}$ of elemental calcium with $200 \mathrm{IU}$ of vitamin D3 twice a day or placebos for $\sim 7$ years. Authors reported a statistically significant increase in the incidence of renal stones. ${ }^{54}$ However, other studies have not found similar results and factors such as an increased oxalate intake and reduced intakes of liquids have been suggested as risk factors in the formation of renal stones rather than the calcium and vitamin D supplementation. ${ }^{55,56}$ Data on the intake of calcium and vitamin D for the prevention of osteoporosis in Indian women are scarce; however, Indian government programs provide calcium supplementation $(500 \mathrm{mg} / \mathrm{d})$ only during pregnancy and lactation. ${ }^{17} \mathrm{~A}$ study comparing the effect of two different doses (500 IU/d and 1,000 IU/d, both groups received calcium carbonate $1,000 \mathrm{mg} / \mathrm{d}$ ) of oral vitamin D3 (cholecalciferol) on serum 25-hydroxy vitamin D [25(OH)-D] concentrations in healthy postmenopausal Indian women concluded that higher doses of vitamin D (1,000 IU) with calcium carbonate were required for the achievement of optimum serum $25(\mathrm{OH})$-D concentrations $(>30 \mathrm{ng} / \mathrm{mL}){ }^{57}$

In the presence of osteoporosis or increased fracture risk, therapy with calcium and vitamin D is insufficient and calls for pharmacological therapy in the form of antiresorptive medications or anabolic drugs. The guidelines for the management of osteoporosis by the Indian Menopausal Society suggest that pharmacological treatment should be initiated in women presenting with fragility fractures, asymptomatic vertebral fractures, those with osteoporosis at the hip or spine (ie, $T$-score of $<-2.5$ ), and in women with secondary causes for osteoporosis or who are at high risk of fractures. ${ }^{49}$ However, the National Osteoporosis Foundation (USA) guidelines further suggest that in postmenopausal women with low bone mass ( $T$-score between -1.0 and -2.5 , ie, osteopenia) at the femoral neck, total hip, or lumbar spine by DXA and a 10-year hip fracture probability $>3 \%$ or a 10 -year major osteoporosisrelated fracture probability $>20 \%$ based on the fracture risk model is also an indication for pharmacologic therapy. ${ }^{52}$

\section{Bisphosphonates}

Bisphosphonates are usually the first line of drugs used when pharmacological therapy is instituted. In India, most bisphosphonates, that is, alendronate daily, risedronate weekly, ibandronate monthly, and zoledronic acid yearly are available and commonly used along with calcium and vitamin D supplementation. ${ }^{19,58}$ Alendronate and risedronate reduce the incidence of fractures of spine and hip by $\sim 40 \%-50 \%>3$ years in patients with prior vertebral fracture. Risedronate is associated with up to $49 \%$ reduction in new vertebral fracture in women with prior vertebral fractures. Ibandronate reduces vertebral fractures by $62 \%$, 
while zoledronic acid, given by intravenous infusion yearly, reduces the incidence of vertebral fracture by $70 \%{ }^{52}$

In a study assessing treatment algorithms in patients with osteoporosis in India, most clinicians opined that they used bisphosphonates as the first-line therapy in almost all patients with osteoporosis. ${ }^{59}$ In a study designed to evaluate the role of isosorbide mononitrate and alendronate in the management of postmenopausal osteoporosis in Indian postmenopausal women, authors found an increase of almost $12 \%$ in the mean BMD at the lumbar spine after 9 months of treatment with alendronate. ${ }^{60}$ However, in a study that aimed to evaluate the adherence and compliance of postmenopausal osteoporotic women for different regimens of bisphosphonates in Indian postmenopausal women, authors found that an adherence rate of $56 \%$ was found with the monthly regimens, $36 \%$ for weekly regimens, and $32 \%$ for daily regimens. Thus, the authors concluded that overall compliance for treatment was poor and that there was need for extensive pre- and continuous posttreatment counseling and follow-up. ${ }^{58}$

The adverse events that have commonly been associated with alendronate are nausea, epigastric pain, and heart burn. However, long-term bisphosphonate therapy may increase the risk of atypical femoral fractures and may lead to prolonged suppression of bone remodeling. ${ }^{61,62}$ Reports also describe other rare complications such as osteonecrosis of the jaw postdental treatment, atrial fibrillation, and esophageal cancer. ${ }^{63,64}$

Drug holidays should only be considered in low-risk patients and in selected patients at moderate risk of fracture after 3-5 years of therapy. When bisphosphonates are prescribed to patients who are at a high risk of fracture, their antifracture benefits considerably outweigh their potential for harm. ${ }^{65}$ Thus, high-risk patients with osteoporosis or patients with history of fragility fractures should not be advised a bisphosphonate holiday. Patients at moderate risk of fractures may be candidates for drug holiday. ${ }^{64}$

\section{Hormone replacement therapy}

After menopause, due to the lack of estrogens, the rate of bone turnover increases, resulting in accelerated bone loss. Indian guidelines for the treatment of postmenopausal osteoporosis advice that therapy with estrogen may be used for prevention and treatment of osteoporosis in the early postmenopausal period in women who are symptomatic. Therapy with estrogen or estrogen and progesterone is believed to prevent osteoporotic fractures and increase lumbar spine and femoral neck BMD over a period of 3 years. ${ }^{49}$ Indian data on the uptake of HRT are scarce; even so, studies suggest that the awareness and use of HRT are much lower among Asian women than their Caucasian counterparts. ${ }^{66}$ In a study that was aimed to assess the antiresorptive effect of hormone therapy and oral ibandronate in postmenopausal osteoporotic women, authors measured BMD and bone turnover markers (C-terminal telopeptide of type I collagen) during the 6-month treatment period. There was an increase in BMD in both groups; however, the group on ibandronate had a significantly greater increase in BMD and reduction in C-terminal telopeptide than the group on HRT. ${ }^{67}$ In a study that aimed to step up the efforts to optimize the management of osteoporotic patients in India, data on current opinion and practices for managing osteoporosis patients in India were collected. Majority of clinicians dealing with osteoporosis opined that though they were aware of the possible risks of cancer and cardiovascular risk due to the intake of estrogens, HRT was still used in perimenopausal osteoporosis as it helped to additionally tide over menopausal symptoms and the patients were shifted to bisphosphonates in due course of time. ${ }^{59}$

Women who have not had a hysterectomy require progestins with estrogen to protect the uterine lining. The WHI found that 5 years of estrogen with progestin while reducing the risk of vertebral and hip fractures also increased risks of myocardial infarction, stroke, invasive breast cancer, pulmonary emboli, and deep vein phlebitis during the 5 years of treatment with conjugated equine estrogen and medroxyprogesterone. In the estrogen only arm of WHI, no increase in breast cancer incidence was noted $>7.1$ years of treatment. ${ }^{68}$ Thus, because of the risks involved, it has been recommended that HRT be used in the lowest effective doses for the shortest duration to meet treatment goals. ${ }^{69}$ However, in an extended follow-up of the WHI study aimed to assess the influence of estrogen use on longer-term breast cancer incidence, authors found that after a median follow-up of 11.8 years, the use of estrogen for a median of 5.9 years was associated with lower incidence of invasive breast cancer. In a subgroup analyses, authors also noted breast cancer risk reduction with estrogen use in women without benign breast disease or a family history of breast cancer. ${ }^{70}$ Further, a long-term follow-up of the WHI cohort suggests that starting HRT in postmenopausal women $<10$ years from last menstrual period, with estrogen alone appears to have less risk. Reports also suggest that HRT administered to postmenopausal women $<60$ years of age may be more beneficial for symptom control, prevention of bone loss, and improving metabolic profile..$^{71}$

With these reservations about HRT, selective estrogen receptor modulators, especially raloxifene, present another treatment option for postmenopausal women. ${ }^{72}$ 


\section{Estrogen agonists}

Raloxifene hydrochloride with a dose of $60 \mathrm{mg} / \mathrm{d}$ is a selective estrogen receptor modulator indicated for the prevention and treatment of postmenopausal osteoporosis. In the Multiple Outcomes of Raloxifene Evaluation (MORE) study, which was a large trial on use of raloxifene, 7,705 postmenopausal women with osteoporosis were treated with raloxifene at a dosage of $60-120 \mathrm{mg} / \mathrm{d}$ or with a placebo for 3 years. The study concluded that after 1 year, raloxifene $60 \mathrm{mg} / \mathrm{d}$ decreased the risk of new clinical vertebral fractures by $68 \%$ compared to placebo in the overall study population and by $60 \%$ in women with prevalent vertebral fractures, who are at a greater risk of subsequent fractures. ${ }^{73}$ In a study conducted in New Delhi to determine the effect of raloxifene on bone loss by quantitative ultrasound and bone turnover markers (bone-specific alkaline phosphatase) in postmenopausal women with osteopenia/osteoporosis over a 6-month period, authors found that there was no significant improvement in BMD over the 6-month treatment period. However, raloxifene had a favorable effect on bone turnover as judged by a significant fall in serum bone-specific alkaline phosphatase. ${ }^{74}$

\section{Calcitonin}

Calcitonin reduces the occurrence of vertebral fractures by $\sim 30 \%$ in women with prior vertebral fractures, but it has not been shown to reduce the risk of nonvertebral fractures. ${ }^{52}$ Since it is administered as a single-daily intranasal spray, compliance is likely to be higher. Supplementation with calcium and vitamin $\mathrm{D}$ is mandatory with calcitonin. Though calcitonin is also an antiresorptive agent, it is believed to have weaker action than the other agents. ${ }^{75}$

In an open-label, prospective, multicentric, single-arm postmarketing surveillance study, efficacy and safety of calcitonin nasal spray in the treatment of osteoporotic back pain in postmenopausal women were studied. There was a significant improvement in pain and quality of life. The use of analgesics was significantly lower after treatment with calcitonin nasal spray. Hence, authors concluded that treatment with calcitonin nasal spray was associated with significant improvement in back pain and quality of life among postmenopausal Indian osteoporotic women. ${ }^{76}$

Studies have also reported the use of combination therapies with calcitonin. The effects of teriparatide with salmon calcitonin treatment on changes in BMD, biochemical bone markers, and safety in postmenopausal Asian women with osteoporosis were studied. Both treatments were similarly tolerated; however, teriparatide was associated with greater increases in lumbar spine BMD and bone formation markers, demonstrating the unique mechanism of action and safety of this treatment for osteoporosis in Asian women. ${ }^{77}$

HRTs, bisphosphonates, calcitonin, and estrogen agonists, are antiresorptive therapies, which result in the increase in bone mass due to inhibition of resorption of bone; however, patients with osteoporosis have lost skeletal mass of $>25 \%$ of normal. Thus, even after treatment with these drugs, many patients still have a BMD that remains within the osteoporotic range $^{78}$ and many continue to have the risk of fracture. Thus, drugs that stimulate the function of osteoblasts, the so-called bone anabolic therapies, are necessary for replacing lost bone or for rebuilding new bone.

\section{Parathyroid hormone}

Intermittent parathyroid hormone (PTH) is a bone anabolic therapy and increases BMD by restoring trabecular microarchitecture. It is also believed to reduce fracture risk to a greater extent than the antiresorptive therapies. ${ }^{79}$ However, PTH has been associated with an increased risk of osteogenic sarcoma in rats, and daily injection of PTH can negatively impact the treatment adherence.

A study was conducted to evaluate the efficacy of teriparatide in increasing BMD in postmenopausal Indian women with osteoporosis. The study was a randomized, prospective, multicenter, open-label, controlled study on 82 postmenopausal women. There was an excellent compliance to both oral and injectable medication. Teriparatide, which is a recombinant human $\mathrm{PTH}$, given to patients was well-tolerated, and there were no serious adverse events. The percentage increase in lumbar spine BMD was significantly higher in teriparatide group compared to the control group (6.6\% vs $1.06 \%)$. The administration of teriparatide also resulted in a significant increase in bone biomarkers. ${ }^{80}$

In a case report on a 62-year-old postmenopausal Indian woman with tensile type of fracture neck femur, who had impaired fracture healing, healing was achieved with the use of recombinant $\mathrm{PTH} .{ }^{81}$

\section{Receptor activator of nuclear factor- kappaB ligand inhibitor (Denosumab)}

Denosumab is a human monoclonal antibody; it binds to receptor activator of nuclear factor-kappaB ligand (RANKL), a transmembrane or soluble protein essential for the formation and function of osteoclasts, which are the cells responsible for bone resorption. Denosumab prevents RANKL from activating its receptor, RANK, on the surface of osteoclasts and their precursors. Prevention of the RANKL/RANK interaction inhibits osteoclast formation, function, and 
survival, thereby decreasing bone resorption and increasing bone mass and strength in both cortical and trabecular bone. By this mechanism, denosumab reduces bone resorption and increases BMD. It is available as $60 \mathrm{mg} / \mathrm{mL}$ in prefilled syringes and approved for osteoporosis in postmenopausal women (60 mg sc twice yearly).

A double-blind, multicenter, Phase III study was conducted in 250 Indian postmenopausal women aged 55-75 years who were randomized to receive one subcutaneous dose of denosumab $60 \mathrm{mg}$ or placebo. All subjects received oral calcium $\geq 1,000 \mathrm{mg}$ and vitamin $\mathrm{D} 3 \geq 400 \mathrm{IU}$ daily. Authors found that denosumab was well-tolerated and effective in increasing BMD and decreasing bone turnover markers over a 6-month period in Indian postmenopausal women. ${ }^{82}$

Very few reports are available in the Indian context for denosumab as the drug is, as yet, not easily available in India.

Thus, several treatment options are available for the treatment of Indian women with osteoporosis. Since most of the expenses for osteoporosis and fracture treatments are paid by the patients ( $<10 \%$ have an insurance cover), the diagnosis as well as the treatment options are decided not only by the nature of the disorder but also by the affordability and availability of treatment options. ${ }^{19}$ Reports suggest that a sizable number of patients who have osteoporotic fractures still go untreated, ${ }^{83}$ thus underlining the fact that this common disorder, which is a major public health problem, needs more attention from health care researchers and providers.

\section{Conclusion}

In conclusion, bone health can be optimized by creating an environment to achieve peak bone mass during adolescence, maintenance of healthy bone throughout the life cycle, and prevention of bone loss postmenopausally. In Indian women, increasing longevity and risk factors, such as low calcium intakes, vitamin D deficiency, sex inequality, early menopause, genetic predisposition, lack of diagnostic facilities, and poor knowledge of bone health, have contributed toward the high prevalence of osteoporosis and fractures. Calcium, vitamin $\mathrm{D}$, and bisphosphonates are the commonest first-line therapies used. The use of other drugs, such as HRT, estrogen agonists, calcitonin, PTH, and denosumab, are decided as per the affordability and availability of treatment options. Major gaps still remain in the diagnosis and management of osteoporosis, thus highlighting the need for more structured research in this area.

\section{Funding}

Ms Rubina Mandlik was funded by a Fellowship Grant from the University Grants Commission (UGC), Government of India.

\section{Disclosure}

The authors declare no conflicts of interest in this work.

\section{References}

1. Kanis JA, Delmas P, Burckhardt P, Cooper C, Torgerson D. Guidelines for diagnosis and management of osteoporosis. The European Foundation for Osteoporosis and Bone Disease. Osteoporos Int. 1997; 7(4):390-406

2. Government of India: Ministry of Home Affairs. Office of the Registrar General and Census Commissioner, India; 2011. Available from: http:// censusindia.gov.in/. Accessed May 3, 2015.

3. Mithal A, Kaur P. Osteoporosis in Asia: a call to action. Curr Osteoporos Rep. 2012;10(4):245-247.

4. Khadilkar A, Mughal MZ, Hanumante N, et al. Oral calcium supplementation reverses the biochemical pattern of parathyroid hormone resistance in underprivileged Indian toddlers. Arch Dis Child. 2009; 94(12):932-937.

5. Khadilkar A, Das G, Sayyad M, et al. Low calcium intake and hypovitaminosis D in adolescent girls. Arch Dis Child. 2007;92(11):1045.

6. Puri S, Marwaha RK, Agarwal N, et al. Vitamin D status of apparently healthy schoolgirls from two different socioeconomic strata in Delhi: relation to nutrition and lifestyle. Br J Nutr. 2008;99(4):876-882.

7. Seth A, Marwaha RK, Singla B, et al. Vitamin D nutritional status of exclusively breast fed infants and their mothers. J Pediatr Endocrinol Metab. 2009;22(3):241-246.

8. Kadam N, Chiplonkar S, Khadilkar A, Divate U, Khadilkar V. Low bone mass in urban Indian women above 40 years of age: prevalence and risk factors. Gynecol Endocrinol. 2010;26(12):909-917.

9. Tandon VR, Sharma S, Mahajan S, et al. Prevalence of vitamin D deficiency among Indian menopausal women and its correlation with diabetes: a first Indian cross sectional data. J Midlife Health. 2014; 5(3):121-125.

10. Ohlsson C, Bengtsson BA, Isaksson OG, Andreassen TT, Slootweg MC. Growth hormone and bone. Endocr Rev. 1998;19(1):55-79.

11. Nutrient Requirements and Recommended Dietary Allowances for Indians: A Report of the Expert Group of the Indian Council of Medical Research; 2009. Hyderabad: National Institute of Nutrition; Indian Council of Medical Research.

12. Ritu G, Gupta A. Vitamin D deficiency in India: prevalence, causalities and interventions. Nutrients. 2014;6(2):729-775.

13. National Institute of Nutrition; Indian Council of Medical Research. Dietary Guidelines for Indians: A Manual. 2nd ed.; 2011. Available from: http://ninindia.org/DietaryGuidelinesforNINwebsite.pdf. Accessed May 3, 2015.

14. Gupta MD. Selective discrimination against female children in rural Punjab, India. Popul Dev Rev. 1987;13(1):77-100.

15. Sanwalka NJ, Khadilkar AV, Mughal MZ, et al. A study of calcium intake and sources of calcium in adolescent boys and girls from two socioeconomic strata, in Pune, India. Asia Pac J Clin Nutr. 2010;19(3): 324-329.

16. Subramaniam R. Gender-bias in India: the importance of household fixed-effects. Oxf Econ Pap. 1996;48(2):280-299.

17. Government of India: Ministry of Women and Child Development. Revised Nutritional and Feeding Norms for Supplementary nutrition in ICDS Scheme; 2009. Available from: http://wcd.nic.in/fnb/fnb/ guidelines/univ_icds5.pdf. Accessed May 3, 2015.

18. Khadilkar AV. Vitamin D deficiency in Indian adolescents. Indian Pediatr. 2010;47(9):755-756. 
19. Mithal A, Bansal B, Kyer CS, Ebeling P. The Asia-Pacific regional audit-epidemiology, costs, and burden of osteoporosis in India 2013: a report of International Osteoporosis Foundation. Indian J Endocrinol Metab. 2014;18(4):449-454.

20. Shetty S, Kapoor N, Naik D, Asha HS, Thomas N, Paul TV. The impact of the Hologic vs the ICMR database in diagnosis of osteoporosis among South Indian subjects. Clin Endocrinol (Oxf). 2014;81(4): 519-522.

21. Pande K, Pande S, Tripathi S, Kanoi R, Thakur A, Patle S. Poor knowledge about osteoporosis in learned Indian women. J Assoc Physicians India. 2005;53:433-436

22. Malhotra N, Mithal A. Osteoporosis in Indians. Indian JMed Res. 2008; 127(3):263-268

23. Marshall D. Meta-analysis of how well measures of bone mineral density predict occurrence of osteoporotic fractures. BMJ. 1996;312:1254.

24. Marwaha RK, Tandon N, Gupta Y, et al. The prevalence of and risk factors for radiographic vertebral fractures in older Indian women and men: Delhi Vertebral Osteoporosis Study (DeVOS). Arch Osteoporos. 2012;7(1-2):201-207.

25. Gupta A. Osteoporosis in India-the nutritional hypothesis. Natl Med J India. 1996;9(6):268-274.

26. Dhanwal DK, Siwach R, Dixit V, Mithal A, Jameson K, Cooper C. Incidence of hip fracture in Rohtak district, North India. Arch Osteoporos. 2013;8(1-2):135.

27. Parker SE, Troisi R, Wise LA, et al. Menarche, menopause, years of menstruation, and the incidence of osteoporosis: the influence of prenatal exposure to diethylstilbestrol. J Clin Endocrinol Metab. 2014; 99(2):594-601.

28. Bharadwaj JA, Kendurkar SM, Vaidya PR. Age and symptomatology of menopause in Indian women. J Postgrad Med. 1983;29(4):218-222.

29. Palacios S, Henderson VW, Siseles N, Tan D, Villaseca P. Age of menopause and impact of climacteric symptoms by geographical region. Climacteric. 2010;13(5):419-428.

30. Keramat A, Patwardhan B, Larijani B, et al. The assessment of osteoporosis risk factors in Iranian women compared with Indian women. BMC Musculoskelet Disord. 2008;9:28.

31. Unni J, Garg R, Pawar R. Bone mineral density in women above 40 years. J Midlife Health. 2010;1(1):19-22.

32. Babu AS, Ikbal FM, Noone MS, Joseph AN, Samuel P. Osteoporosis and osteopenia in India: a few more observations. Indian J Med Sci. 2009; 63(2):76-77.

33. Marwaha RK, Tandon N, Garg MK, et al. Bone health in healthy Indian population aged 50 years and above. Osteoporos Int. 2011;22(11): 2829-2836.

34. Mehta G, Taylor P, Petley G, Dennison E, Cooper C, Walker-Bone K. Bone mineral status in immigrant Indo-Asian women. QJM. 2004; 97(2):95-99.

35. Pothiwala P, Evans EM, Chapman-Novakofski KM. Ethnic variation in risk for osteoporosis among women: a review of biological and behavioral factors. J Womens Health (Larchmt). 2006;15(6):709-719.

36. Mitra S, Desai M, Ikram Khatkhatay M. Vitamin D receptor gene polymorphisms and bone mineral density in postmenopausal Indian women. Maturitas. 2006;55(1):27-35.

37. Zajícková K, Zofková I, Bahbouh R, Krepelová A. Vitamin D receptor gene polymorphisms, bone mineral density and bone turnover: FokI genotype is related to postmenopausal bone mass. Physiol Res. 2002; 51(5):501-509.

38. Mitra S, Desai M, Khatkhatay MI. Association of estrogen receptor alpha gene polymorphisms with bone mineral density in postmenopausal Indian women. Mol Genet Metab. 2006;87(1):80-87.

39. Albagha OM, Pettersson U, Stewart A, et al. Association of oestrogen receptor $\alpha$ gene polymorphisms with postmenopausal bone loss, bone mass, and quantitative ultrasound properties of bone. J Med Genet. 2005; 42(3):240-246.

40. Harinarayan CV, Ramalakshmi T, Prasad UV, et al. High prevalence of low dietary calcium, high phytate consumption, and vitamin $\mathrm{D}$ deficiency in healthy south Indians. Am J Clin Nutr. 2007;85(4):1062-1067.
41. Tandon N, Marwaha RK, Kalra S, Gupta N, Dudha A, Kochupillai N. Bone mineral parameters in healthy young Indian adults with optimal vitamin D availability. Natl Med J India. 2003;16(6):298-302.

42. Paul TV, Thomas N, Seshadri MS, Oommen R, Jose A, Mahendri NV. Prevalence of osteoporosis in ambulatory postmenopausal women from a semiurban region in Southern India: relationship to calcium nutrition and vitamin D status. Endocr Pract. 2008;14(6):665-671.

43. Arya V, Bhambri R, Godbole MM, Mithal A. Vitamin D status and its relationship with bone mineral density in healthy Asian Indians. Osteoporos Int. 2004;15(1):56-61.

44. Shivane VK, Sarathi V, Bandgar T, Menon P, Shah NS. High prevalence of hypovitaminosis D in young healthy adults from the western part of India. Postgrad Med J. 2011;87(1030):514-518.

45. Vupputuri MR, Goswami R, Gupta N, Ray D, Tandon N, Kumar N. Prevalence and functional significance of 25-hydroxyvitamin D deficiency and vitamin D receptor gene polymorphisms in Asian Indians. Am J Clin Nutr. 2006;83(6):1411-1419.

46. Mahan LK, Escott-Stump S, Raymond JL. Krause's Food and the Nutrition Care Process. 13th ed. St Louis: Elsevier; 2012.

47. Aggarwal N, Raveendran A, Khandelwal N, et al. Prevalence and related risk factors of osteoporosis in peri- and postmenopausal Indian women. J Midlife Health. 2011;2(2):81-85.

48. Kumar A, Mittal S, Orito S, Ishitani K, Ohta H. Impact of dietary intake, education, and physical activity on bone mineral density among North Indian women. J Bone Miner Metab. 2010;28(2):192-201.

49. Meeta, Harinarayan CV, Marwah R, Sahay R, Kalra S, Babhulkar S. Clinical practice guidelines on postmenopausal osteoporosis: an executive summary and recommendations. J Midlife Health. 2013;4(2): $107-126$.

50. Agrawal T, Verma AK. Cross sectional study of osteoporosis among women. Med J Armed Forces India. 2013;69(2):168-171.

51. Jha RM, Mithal A, Malhotra N, Brown EM. Pilot case-control investigation of risk factors for hip fractures in the urban Indian population. BMC Musculoskelet Disord. 2010;11:49.

52. Cosman F, de Beur SJ, LeBoff MS, et al. Clinician's guide to prevention and treatment of osteoporosis. Osteoporosis Int. 2014;25(10): 2359-2381.

53. Tang BM, Eslick GD, Nowson C, Smith C, Bensoussan A. Use of calcium or calcium in combination with vitamin $\mathrm{D}$ supplementation to prevent fractures and bone loss in people aged 50 years and older: a meta-analysis. Lancet. 2007;370(9588):657-666. [Erratum in: Lancet. 2012;380(9844):806].

54. Jackson RD, LaCroix AZ, Gass M, et al; Women's Health Initiative Investigators. Calcium plus vitamin D supplementation and the risk of fractures. $N$ Engl J Med. 2006;354(7):669-683. [Erratum in: $N$ Engl J Med. 2006;354(10):1102].

55. Borghi L, Schianchi T, Meschi T, et al. Comparison of two diets for the prevention of recurrent stones in idiopathic hypercalciuria. $N$ Engl J Med. 2002;346(2):77-84.

56. Sunyecz JA. The use of calcium and vitamin D in the management of osteoporosis. Ther Clin Risk Manag. 2008;4(4):827-836.

57. Agarwal N, Mithal A, Dhingra V, Kaur P, Godbole MM, Shukla M. Effect of two different doses of oral cholecalciferol supplementation on serum 25-hydroxy-vitamin D levels in healthy Indian postmenopausal women: a randomized controlled trial. Indian J Endocrinol Metab. 2013;17(5):883-889.

58. Tandon VR, Sharma S, Mahajan S, Mahajan A, Khajuria V, Gillani Z. First Indian prospective randomized comparative study evaluating adherence and compliance of postmenopausal osteoporotic patients for daily alendronate, weekly risedronate and monthly ibandronate regimens of bisphosphonates. J Midlife Health. 2014;5(1):29-33.

59. Lakhotia SM, Dongre P. Treatment algorithm for Indian patients of osteoporosis. Ind Med Gaz. 2012;47(2):67-77.

60. Duhan N, Siwach RC, Yadav K, Dahiya K, Nanda S, Sirohiwal D. Comparative evaluation of isosorbide mononitrate and alendronate in management of postmenopausal osteoporosis. Arch Gynecol Obstet. 2012; 285(4):1019-1023. 
61. Bhadada SK, Sridhar S, Muthukrishnan J, et al. Predictors of atypical femoral fractures during long term bisphosphonate therapy: a case series and review of literature. Indian J Med Res. 2014;140(1):46-54.

62. Mashiba T, Hirano T, Turner CH, Forwood MR, Johnston CC, Burr DB. Suppressed bone turnover by bisphosphonates increases microdamage accumulation and reduces some biomechanical properties in dog rib. J Bone Miner Res. 2000;15(4):613-620.

63. Gupta S, Gupta H, Mandhyan D, Srivastava S. Bisphophonates related osteonecrosis of the jaw. Natl J Maxillofac Surg. 2013;4(2):151-158.

64. Brown JP, Morin S, Leslie W, et al. Bisphosphonates for treatment of osteoporosis: expected benefits, potential harms, and drug holidays. Can Fam Physician. 2014;60(4):324-333.

65. McClung M, Harris ST, Miller PD, et al. Bisphosphonate therapy for osteoporosis: benefits, risks, and drug holiday. Am J Med. 2013;126(1): 13-20.

66. Huang KE. Menopause perspectives and treatment of Asian women. Semin Reprod Med. 2010;28(5):396-403.

67. Srividhya NB, Singh N, Goel N, Gambhir JK, Rathi V, Rajaram S. Comparison of antiresorptive effect of hormone therapy and ibandronate in postmenopausal osteoporotic women by assessing type I collagen C-telopeptide levels. Post Reprod Health. 2015;21(2):48-55.

68. Rossouw JE, Anderson GL, Prentice RL, et al; Writing Group for the Women's Health Initiative Investigators. Risks and benefits of estrogen plus progestin in healthy postmenopausal women. JAMA. 2002; 288(3):321-333.

69. North American Menopause Society. Estrogen and progestogen use in postmenopausal women: 2010 position statement of The North American Menopause Society. Menopause. 2010;17(2):242-255.

70. Anderson GL, Chlebowski RT, Aragaki AK, et al. Conjugated equine oestrogen and breast cancer incidence and mortality in postmenopausal women with hysterectomy: extended follow-up of the women's health initiative randomised placebo-controlled trial. Lancet Oncol. 2012;13(5):476-486. doi:10.1016/S1470-2045(12)70075-X.

71. Gurney EP, Nachtigall MJ, Nachtigall LE, Naftolin F. The women's health initiative trial and related studies: 10 years later: a clinician's view. J Steroid Biochem Mol Biol. 2014;142:4-11. doi:10.1016/j. jsbmb.2013.10.009.

72. Spencer CP, Morris EP, Rymer JM. Selective estrogen receptor modulators: women's panacea for the next millennium? Am J Obstet Gynecol. 1999; 180(3 pt 1):763-770.

73. Jolly EE, Bjarnason NH, Neven P, et al. Prevention of osteoporosis and uterine effects in postmenopausal women taking raloxifene for 5 years. Menopause. 2003;10(4):337-344.

74. Agrawal S, Jain A, Mahajan D, Raghunandan C. Correlation of bone mineral density with biochemical markers in post-menopausal women. Indian J Clin Biochem. 2009;24(3):262-265.
75. Ozoran K, Yildirim M, Önder M, Sivas F, Inanir A. The bone mineral density effects of calcitonin and alendronate combined therapy in patients with rheumatoid arthritis. APLAR J Rheumatol. 2007;10(1): $17-22$.

76. Iyer RN, Purohit V, Karankumar J, Ahluwalia AK. Assessment of efficacy, safety and quality of life in postmenopausal women with osteoporosis using salmon calcitonin nasal spray. Asian J Pharm Clin Res. 2013;6(2):117-119.

77. Kung AW, Pasion EG, Sofiyan M, et al. A comparison of teriparatide and calcitonin therapy in postmenopausal Asian women with osteoporosis: a 6-month study. Curr Med Res Opin. 2006;22(5):929-937.

78. Hodsman AB, Hanley DA, Ettinger MP, et al. Efficacy and safety of human parathyroid hormone-(1-84) in increasing bone mineral density in postmenopausal osteoporosis. J Clin Endocrinol Metab. 2003; 88(11):5212-5220.

79. Lane NE, Kelman A. A review of anabolic therapies for osteoporosis. Arthritis Res Ther. 2003;5(5):214-222.

80. Sethi BK, Chadha M, Modi KD, Kumar KM, Mehrotra R, Sriram U. Efficacy of teriparatide in increasing bone mineral density in postmenopausal women with osteoporosis - an Indian experience. J Assoc Physicians India. 2008;56:418-424.

81. Malhotra R, Meena S, Digge VK. Tensile type of stress fracture neck of femur: role of teriparatide in the process of healing in a high risk patient for impaired healing of fracture. Clin Cases Miner Bone Metab. 2013;10(3):210-212.

82. Pitale $\mathrm{S}$, Thomas $\mathrm{M}$, Rathi $\mathrm{G}$, et al. A randomized placebo-controlled trial of the efficacy of denosumab in Indian postmenopausal women with osteoporosis. Indian J Endocrinol Metab. 2015;19(1):148-154.

83. Varthakavi PK, Joshi AS, Bhagwat NM, Chadha MD. Osteoporosis treatment in India: call for action. Indian J Endocrinol Metab. 2014; 18(4):441-442.

84. Gandhi AB, Shukla AK. Evaluation of BMD of women above 40 years of age. J Obstet Gynecol India. 2005;55(3):265-267.

85. Shatrugna V, Kulkarni B, Kumar PA, Rani KU, Balakrishna N. Bone status of Indian women from a low-income group and its relationship to the nutritional status. Osteoporos Int. 2005;16(12):1827-1835.

86. Sharma S, Tandon VR, Mahajan A, Kour A, Kumar D. Preliminary screening of osteoporosis and osteopenia in urban women from Jammu using calcaneal QUS. Indian J Med Sci. 2006;60(5):183-189.

87. Chhibber G, Roy R, Eunice M, Srivastava M, Ammini AC. Prevalence of osteoporosis among elderly women living in Delhi and rural Haryana. IJEM. 2007;11(1):11-14.

88. Vaidya SV, Ekbote VH, Khadilkar AV, Chiplonkar SA, Pillay D, Divate U. Bone status of women over 40 years of age from two socioeconomic strata. Endocr Res. 2012;37(1):25-34.
International Journal of Women's Health

\section{Publish your work in this journal}

The International Journal of Women's Health is an international, peerreviewed open-access journal publishing original research, reports, editorials, reviews and commentaries on all aspects of women's healthcare including gynecology, obstetrics, and breast cancer. The manuscript management system is completely online and includes
Dovepress

a very quick and fair peer-review system, which is all easy to use. Visit http://www.dovepress.com/testimonials.php to read real quotes from published authors. 